\title{
The Cook and the Writer: Maryse Condé's Journey of Self- Discovery
}

\section{Bonnie Thomas, University of Western Australia}

In an interview with Paola Ghinelli, celebrated Guadeloupean writer Maryse Condé draws on an evocative metaphor to affirm her identity: 'J'ai avalé toute une série de réalités et je suis le résultat de ces mélanges’ (Ghinelli 2005: 43). ${ }^{1}$ Condé’s recent writings reveal a preoccupation with self-understanding, culminating in her 2012 autobiographical narrative La Vie sans fards (Life Without Embellishment), in which she attempts to recount her life without resorting to self-aggrandizement. Condé affirms in a 2010 interview that knowing herself is crucially linked to knowing her place within her female genealogy: 'Chez nous aux Antilles toutes les généalogies doivent passer par les femmes’ (Carruggi 2010: 210). ${ }^{2}$ This article aims to reveal how Condé’s 2006 memoir, Victoire, les saveurs et les mots ${ }^{3}$ - a work of autofiction in which she imagines her maternal grandmother's life-allows her to place herself within such a female continuum. Drawing on one of the few facts she knows about Victoire-that she was a cook-Condé reinforces the intimate connection between history, memory and food in her memoir, bringing forth a profound link between the generations of women that precede her. In this way she ensures her family histories form part of a greater narrative of the Caribbean. Condé's nomadic background makes her particularly attuned to the

\footnotetext{
1 'I swallowed a whole series of realities and I am the result of these mixes.' All translations in this paper are my own with the exception of published translations of Condé's work.

2 'For us in the French Caribbean, all genealogies must pass through women.'

3 Translated into English in 2010 with the title Victoire: My Mother's Mother. Hereafter, reference to the novel will be abbreviated to Victoire.
}

PORTAL Journal of Multidisciplinary International Studies, vol. 10, no. 2, July 2013.

Edible Alterities: Perspectives from La Francophonie Special Issue, guest edited by Angela

Giovanangeli and Julie Robert.

ISSN: 1449-2490; http://epress.lib.uts.edu.au/ojs/index.php/portal

PORTAL is published under the auspices of UTSePress, Sydney, Australia. 
transnational and polyphonic nature of her Caribbean identity and she reveals that food provides both a literal and figurative vehicle for the reappraisal of her history.

The theoretical background to this discussion draws on two principal sources-first, Edouard Glissant's concept of Relation; and second, Antonio Benítez-Rojo’s notion of the polyphonic fugue. Martinican writer Glissant remains one of the foremost theoreticians of the Caribbean and his characterization of Martinique and Guadeloupe as sites of history dominated by ruptures and a brutal dislocation caused by the slave trade is crucial to understanding the French Caribbean context (Glissant 1989: 61). However, Glissant considerably extended his interpretation of these ideas, which he first explored in his 1981 Le Discours antillais, ${ }^{4}$ in works such as Poétique de la Relation (Glissant 1990), ${ }^{5}$ Une Nouvelle Région du monde (Glissant 2006), Quand les murs tombent: l’identité nationale hors-la-loi? (Glissant \& Chamoiseau 2007) and Mémoires des esclavages: la fondation d'un centre national pour la mémoire des esclavages et de leur abolitions (Glissant 2007). Glissant's concept of Relation challenges the idea of a fixed identity and instead encourages a theoretical approach that views elements in relation to one another rather than in oppositional pairings. He employs the image of the rhizome to encapsulate this position with its connotation of a chaotic network of interconnecting roots: 'Rhizomic thought is the principle behind what I call the Poetics of Relation, in which each and every identity is extended through a relationship with the Other’ (Glissant 1997: 11). Relation in this paper displaces the idea of a continuous unfolding of history in which past, present and future relate to each other in an oppositional way. Instead, Relation privileges a network of interrelationships where there is sufficient flexibility to reinterpret seemingly fixed meanings.

On a more personal level, in the case of Condé and her female relatives, a Relational approach means delving into family mythologies in which individuals have been relegated to reductive stereotypes. For example, Condé has always viewed her mother as emotionally absent and difficult in a similar manner to the way in which Jeanne, Condé’s mother, views Victoire. While Condé distances herself from Glissant’s cerebral approach to the past—she notes that 'Glissant is abstract I live, and I draw lessons from what I live, but I don’t have theoretical constructs’ (Alexander et al. 2006: 21)—his

\footnotetext{
${ }^{4}$ Translated into English in 1989 with the title Caribbean Discourse.

${ }^{5}$ Translated into English in 1997 with the title Poetics of Relation.
} 
model of Relation nonetheless proves useful when viewing Condé's reflections on her ancestors. Indeed, one could argue that Condé shows that the discovery and integration of her female genealogy into her personal history constitutes an innovative incarnation of Relation. Critic Nick Nesbitt argues that Condé’s approach to writing history and memory is unique, as she 'opens a space so that the human subject and historical fact can meet ... Condé articulates an individual experience of French Caribbean history, saturated with affectivity' (2002: 115). Condé's work consistently demonstrates how the personal becomes a powerful expression of the political. Nesbitt's assertion highlights the way in which Condé engages with and reinforces the link between History and individual histories, a feat that is achieved in Victoire, through the symbolism of food.

In his now famous 1992 publication The Repeating Island: The Caribbean and the Postmodern Perspective, Antonio Benítez-Rojo draws attention to the plural, rhizomatic nature of the Caribbean. He characterizes the Caribbean as a 'meta-archipelago,' a geographical feature without boundary or centre that conjures up images of 'unstable condensations, turbulences, whirlpools, clumps of bubbles ... in short, a field of observation quite in tune with the objectives of Chaos' (1992: 2-3). Like Glissant, however, Benítez-Rojo stresses that such chaos is not necessarily a negative phenomenon; rather it charaterises a space for new and fruitful connections. BenítezRojo likens the Caribbean to a fugue where all elements are necessary, even those that conflict, in order to create an intricate polyphonic composition (1992: 173). In a place like the Caribbean where there are so many potentially clashing influences_-different languages, cultures and power relations - the image of the fugue allows for the possibility of positive intersection. Benítez-Rojo's framework emphasizing plurality and interconnection adds another layer to analysis of Condé's reminiscences against the backdrop of French Caribbean history. Her attempt to make sense of her female line forms part of a larger search for polyphonic 'order' within a 'chaotic' network of relationships: 'Victoire is an element that allows me to access the truth about my mother and hence about myself. Since I never knew Victoire and have no memory of her, she is only theoretical and abstract, but without her I would never have been able to reach the intimacy that I want with my mother' (Boisseron 2010: 144).

In Victoire Condé interrogates her past for answers to the psychologically disjointed upbringing she experienced as a child and its decisive influence in shaping her global 
outlook later in life. As she states in her essay Pour une littérature-monde, 'je tentai d'expliciter les complexes rapports de ma mère et de ma grand-mère, toute cette avantvie qui influa sur mon comportement’ (2007: 213). ${ }^{6}$ And in a 2010 interview she asserts that she had to 'voir, recréer toute cette généalogie féminine que je connaissais pas’ (Carruggi 2010: 211). ${ }^{7}$ Throughout the narrative Condé uncovers and, in the absence of hard facts, imagines and reconstructs her maternal grandmother Victoire's life. She discovers that, contrary to her mother Jeanne's bourgeois existence as an adult, Jeanne’s childhood was spent in poverty as Victoire hired herself out as a cook. The symbolism of food works in a number of different ways in Victoire. First, Condé establishes food as a symbol of alienation and acculturation to the French way of life. Second, she demonstrates that food constitutes an emotional battleground between the three generations of women where food comes to constitute a language. Third, she uses food as a means to inscribe her grandmother's story in a historical narrative where records of Victoire’s culinary successes act as examples of Pierre Nora’s 'lieux de mémoire, sites of memory’ (1989: 7). Finally, the results of Victoire’s labour in the kitchen help to open the doors to greater autonomy for her daughter and, consequently, her granddaughter. The constant comparisons Condé makes between her grandmother’s occupation as a cook and her own as a writer-'I want to establish the link between her creativity and mine, to switch from the savors, the colors, and the smells of meat and vegetables to those of words' (2010: 59)—constitute a final drawing together of her female relatives in a gesture of Relation.

Before proceeding to an analysis of Condé's text, it is important first to establish the central role that food and cooking play in the history and culture of the Caribbean. According to Brinda Mehta, here speaking of French Guadaloupean author Gisèle Pineau, 'it is impossible to separate the island's [Guadeloupe's] culinary history from its disempowering colonial history of Amerindian genocide, African slavery, Indian and Chinese indenture, and its subsequent consequences of cultural métissage or creolization, migration, survival, and adaptation' (2005: 25). There are a number of pertinent points to consider in relation to this culinary history of conquest and adaptation. First, food became one of many ways in which the colonizing power, France, imposed its will on the dominated cultures of Martinique, Guadeloupe and Marie-

\footnotetext{
${ }^{6}$ 'I tried to make explicit the complex relationships with my mother and grandmother, all this life before mine that influenced my behaviour.'

7 'see, recreate this whole female genealogy that I didn't know.'
} 
Galante. Domestic servants like Victoire were forced to recreate as much as possible the culinary traditions of France in the kitchens of their employers. French food was associated with superiority so that imported products such as apples were more sought after than tropical produce such as mangoes or avocadoes. Moreover, apart from crops such as sugar cane, which remained a symbol of exploitation and oppression after the abolition of slavery in Martinique and Guadeloupe in 1848, local food was overlooked in favour of foreign imports. Consequently, these French Caribbean islands became increasingly dependant upon French aid as they lost the ability to be self-sufficient. As Richard Burton put it, the island departments of Martinique and Guadeloupe became 'all superstructure and no base' (1995: 4). Just like the French language, imported French food attained a certain prestige in comparison to its local counterparts.

On the other hand, food became a means for illiterate domestic workers to achieve a sense of autonomy within their situation to the point where it constituted a kind of language. As Mehta has affirmed in relation to the Guadeloupean writer Gisèle Pineau's grandmother, '[c]ultural production in the form of cooking, cultivation, storytelling, and other forms of cultural discursiveness become [an] alphabet, [a] symbolic system of self-inscription in family and communal history' (2005: 30). In the case of Victoire, her ability in the kitchen achieves her an enviable reputation in her milieu despite her inability to speak French. This sense of autonomy forms a contrast to Jeanne who strives to emulate the French model by expressing herself resolutely in the French language and by being as 'French' as possible. One could draw a parallel here between Victoire and Pineau's grandmother, Man Ya, who also rejects assimilation and remains resolutely herself-a simple peasant woman who is deeply attached to the natural landscape of Guadeloupe and who expresses herself in Creole. Like Condé's parents, Pineau's mother and father subscribe to an assimilationist model of self-advancement, but in both cases the writers underline the painful self-censorship and limitations such an approach entails.

Condé introduces the idea of food as a symbol of alienation and acculturation to the French way of life in her first autobiographical reflection Le Coeur à rire et à pleurer: contes vrais de mon enfance (1999). ${ }^{8}$ This book centres on Condé's childhood in

\footnotetext{
${ }^{8}$ Tales from the Heart: True Stories from my Childhood. Hereafter, reference to this work will be abbreviated to Tales from the Heart.
} 
Guadeloupe and offers insights into her growing awareness of the way in which historical forces imprint themselves upon individual lives. In particular she draws attention to the ongoing influence of France on her daily life and her parents' commitment to assimilating to the French way of life as much as possible. Condé enlists a culinary scene in Tales from the Heart to dramatize the conflict of affirming one's identity in a situation of cultural dominance. The family are on one of their regular trips to France, enjoying a meal at a Parisian café when waiters would arrive at their table: 'Their trays balanced on their hips, the garçons de café would hover around us admiringly like honey bees. Setting down the diabolos menthes, they never failed to come out with: "You speak excellent French, you know!”’ (2001: 4). Condé's parents are outraged, her father declaring that they are as French as the waiters while her mother asserts that they are even more so because they are better educated, have better manners and have travelled more. From their elegant clothes to their very French choice of drink, Monsieur and Madame Boucolon see themselves as indistinguishable from their metropolitan counterparts. For the young Condé, however, this experience provokes a serious questioning of her identity, only deepened when her older brother Sandrino declares that their parents are ‘a pair of alienated individuals’ (2001: 6).

In this café scene Condé’s parents demonstrate a bicultural approach to identity that situates Guadeloupe constantly in relation to France rather than viewing the different aspects of their identity in a relational context. The split that Condé senses between her parents' perception of themselves as exceptional individuals, coupled with the attitude of superiority adopted by the Parisian waiters, marks the beginning of her refusal to be defined by others. While still not fully understanding the concept of alienation, the young Condé eventually comes to the conclusion that an alienated person must be someone who ‘is trying to be what he can't because he does not like what he is' (2001: 7). Condé's description of her overnight transformation from a model of obedience into an obstinate child encapsulates the critical, questioning attitude that is characteristic of her later thought and drives her to interrogate her family through history through Relation. Her parents, in contrast to their daughter, appear stunted in their intellectual growth as they remain fixated on a model of social advancement that is continually oriented towards France. The development of these attitudes proves fundamental in Victoire as they decisively influence the relationships that grow between mother, daughter and granddaughter and are orchestrated through the medium of food. 
In contrast to her depiction of her parents’ assimilationist attitude, Condé empowers Victoire by emphasizing her capacity to create a bridge between two cultures through food. Victoire demonstrates a remarkable ability to create culinary delights that blend and adapt both the foreign and local cultures. For a family christening for her employers, for example, Victoire creates a menu that is an exotic blend of European delights and Caribbean delicacies, including '[c]onch and freshwater fingerling pie. Sea urchin chaud-froid. Fatted chicken caramelized in juniper' (2010: 190). Food and cooking, then, constitute powerful vehicles for the expression of social relations between different classes and cultures. What the menu above underlines is the way in which the values attributed to different classes may vary according to how you interpret them-on the one hand, Victoire may appear to be exploited and limited by her domestic duties; on the other hand, she forges a path of autonomy using food that not only allows her to express herself, but also opens a road towards liberation for her descendants. As a result of Victoire's abilities as a cook she is able to support Jeanne to pursue a career as one of the first black school teachers in Guadeloupe and consequently for Condé to become a leading writer and academic. The progressive upward mobility of this female line is facilitated by the medium of food.

Condé also dramatizes the conflicted relationships in her female genealogy in the way she and her ancestors relate to food. Victoire illustrates that food metamorphoses into a powerful battlefield for the exchange of emotions, resulting in the permanent transformation of the female line. Condé's narrative reveals that Jeanne expresses her feelings towards life in her approach to food. Unlike for Victoire, food for Jeanne is not a source of pleasure or nourishment, but a way of rebelling against her mother and expressing her anger at her situation. When she is angry at Victoire for deserting her in order to follow a man to Martinique, Jeanne loses a significant amount of weight 'as a way of punishing her mother who placed so much importance in [food]' (2010: 96). As Victoire feels increasingly rejected by her daughter, she expresses her emotions by burying herself in the kitchen and 'cooking to excess' (2010: 112). Victoire and Jeanne consistently play out their emotional battles through the indulgence in or rejection of food - to the point where Victoire feels so withdrawn from her daughter that she ultimately loses her literal taste for life. The symbolic intermingling of food and emotion carries over into Condé's own life and she recalls the way her mother became furious when she showed an interest in cooking. She discovers that the acceptance or 
rejection of a culinary role symbolized a far more complex distinction for her mother in which a love of food is likened to oppression and a rejection of it to intellectual superiority: 'Je me suis rendu compte plus tard que c’est parce qu'en fait il y avait un choix: ou bien être intellectuelle comme elle l'était, ou bien être comme ma grand-mère, une femme d'instinct, une femme sans éducation' (Carruggi 2010: 210-11). ${ }^{9}$ However, by asserting in the preface to a book on French Caribbean cuisine that she is an excellent cook as well as a writer (Ovide 2002: 9), Condé shows that identity is no longer a case of either/or, but, rather, a place where previously conflicting elements can coexist. Victoire reveals Condé's overarching desire to find patterns of relation in her family_or polyphonic beauty in Benítez-Rojo’s terms—and therefore to reconcile with her personal and cultural past.

In a different manner, Condé uses her grandmother's culinary talents as a way to inscribe her tale in a larger historical narrative by recording the concrete remains she leaves behind her. Interestingly, despite the difficult relationship between mother and daughter, it is Jeanne who conserves many of these 'traces of the past' as if she is trying to transpose Victoire's worth onto a level that is acceptable among the black bourgeois society to which she joins as a result of her education. Condé recalls hearing her mother constantly asserting that: ' $[\mathrm{m}] \mathrm{y}$ mother could neither read nor write, but without her I wouldn't be where I am today' (2010: 114) and that among 'the papers my mother kept was issue 51 of l'Echo pointois, where right in the middle of a laudatory article appears the menu for this christening banquet, lyrically composed like a poem' (2010: 70). It is as if Jeanne is desperate to remember her mother in a meaningful way, but struggles to do so in a society that rejects the importance of an illiterate domestic who cannot speak French. Jeanne finds herself in a complex web of conflicting demands where Victoire is the one who enables her promotion to bourgeois society, but at the same time, Jeanne must relinquish attachment to her mother in order to accept this position. Jeanne's ambiguous, emotionally detached approach to life reflects her internal struggle as she fights to find a way to reconcile these two very different worlds. In fact it falls to her daughter to forge this reconciliatory network of Relation as if the distance afforded by one generation's remove is the only way to heal from the past.

\footnotetext{
9 'I only realized much later that it was because there was in fact a choice: to be an intellectual as she was, or to be like my grandmother, a woman of instinct, a woman without education.'
} 
Condé strengthens her grandmother's influence by likening Victoire’s creations to a religious experience, in this way reappraising her exclusion from History with a capital 'H'. For example, Reverend Father Moulinet declares that her 'cooking amounted to honoring God’ (2010: 123), ‘the priest in Le Moule extolled Victoire’s merits in his sermon at high mass and called her a true Christian' (2010: 123) and wrote in his diary that it 'is the Almighty who has manifested Himself in her hands' (2010: 125).

Endowed with divine qualities, Victoire is no longer bound to her state of illiteracy, colour, gender and poverty. On the contrary, Condé's grandmother takes on a role of definitive influence. The extraordinary achievement of liberating her descendants from the shackles of subservience provides an overarching and uniting framework for her daughter and grandchildren to follow. Condé's re-evaluation of Victoire’s role provides a bonding link between generations of highly conflicted female relationships.

Condé reinforces the intimate connection between history, memory and food in her recreation of a culinary scene she labels 'The Last Supper'. Victoire is close to death and again it is food to which she turns as a way to leave a final imprint on her descendants' narrative. As Condé imagines this event in her book, she recalls it is an occasion that blends the personal and political: it unites all the people for whom Victoire cares whilst simultaneously allowing her to imagine a better future for her country: 'One day, Guadeloupe would no longer be tortured by questions of class. The white Creoles would learn to be humble and tolerant. There would no longer be the need to set a club of Grands Nègres against them. Both would get along, freely intermingle, and who knows, love each other' (2010: 189). This lunch represents Victoire’s ‘way of writing her last will and testament' (2010: 189) and in a rare moment of intimacy between mother and daughter, Jeanne records the menu of this significant day 'on one of her exercise books that she carefully kept, scribbled with bits of her diary, memos, class timetables, and her children's height and weight' (2010: 189). Food thus becomes a way for Victoire to reach out to her daughter and for her daughter to reciprocate in a way that is meaningful for her. It is interesting that Jeanne chooses to record this culinary experience in written form, in some way forging a bond between all three generations where the cook (Victoire) gradually becomes the writer (Condé).

In an attempt to forge a network of Relation with her female ancestors — indeed, to reconnect the broken links between herself and her mother, and her mother and her 
grandmother-Condé makes repeated comparisons of the cook and the writer in Victoire. Cooking is a way for Victoire to express her creativity in the same way Condé expresses hers through writing. Condé traces the ways in which one’s attitude to one's craft reflects the ebbs and flows of one's life. For example, when Victoire is no longer able to set foot in the kitchen, Condé laments the feeling of uselessness that must assail her, just as she would if she was banned from her computer (2010: 116). When Victoire loses her purpose in life it is because she cannot cook, in the same way that the gift of writing may desert one if one loses the will to live (2010: 171). Victoire's attitude to life is closely mirrored in her attitude to food while for Condé this creative expression is found in writing.

Condé's appreciation of the complexities of French Caribbean identity-both in a global and local context-is a topic that she has discussed in a number of contexts over the years. In a 1991 interview with Françoise Pfaff, for example, Condé discusses the multiplicity of Caribbean identity, arguing that it cannot be reproduced like a recipe for cooking, but, rather, that there are several ways to be Caribbean (2010: 113).

Furthermore, in her 1995 contribution to the edited collection Penser la créolité, 'Chercher nos vérités,' she poses the question 'What is the Caribbean today?' She answers that it is 'a place without definite contours, porous to all distant noises, traversed by all influences, even the most contradictory’ (1995: 309). This emphasis on multiplicity, mutual influence and connection in French Caribbean identity is reflected in Glissant's model of Relation. Condé's autobiographical narratives demonstrate the way in which people need to situate themselves in a Relational network in order to understand both themselves and their country. For Condé this relational feat is achieved through her creative linking of Victoire’s culinary art and Condé's own literary craft. The quest to bond the cook with the writer also allows Condé to better understand her own mother and therefore to create links where before there was disconnection and rupture. Finally she is able to view her mother in her own light, reflecting that both Jeanne and herself have harnessed their memories of Victoire to construct their identities:

In her grief and remorse, Jeanne constructed a myth that barely corresponded to reality and left in the dark uncertain aspects of Victoire's personality. In short, she endeavored at all costs to have her conform to the clichéd norm of the Guadeloupean matador, the fighting woman who courageously resists life's trials. As for me, I prefer my grandmother to remain secretive, enigmatic, the improper architect of a liberation that we, her descendants, have known how to enjoy to the full. (2010: 195) 
Victoire ends with the birth of a baby, Condé's older sister, which underlines the redemptive possibilities of Relation and the importance of family and social connection. Through her reconstruction of her grandmother through literature, Condé succeeds in creating a profound link between the generations of women that precede and descend from her. Victoire reinforces the idea that the writing process and culinary creation are closely related and constitute a means to transform one's future and the legacy that an individual will leave to his or her descendants. Food becomes a metaphor for creativity, acceptance and recovery in a female space; but it is also a symbol of alienation and acculturation to French way of life. Ultimately, the book reveals that it is possible to mend family ties through the sharing of food as well as acting as a metaphor for the reconciliation between the past, present and future.

\section{Reference list}

Alexander, A-M., Broichhagen, V., Koffi-Tessia, M.-H., Lachman, K., and Simek, N. 2006, ‘A Conversation at Princeton with Maryse Condé,' in Feasting on Words: Maryse Condé, Cannibalism, and the Caribbean Text, (eds) V. Broichhagen, K. Lachman, \& N. Simek. Programme in Latin American Studies, Princeton University, Princeton: 1-28.

Benítez-Rojo, A. 1992, The Repeating Island: The Caribbean and the Postmodern Perspective. Duke University Press, Durham, NC, \& London.

Boisseron, B. 2010, 'Intimité: entretien avec Maryse Condé', International Journal of Francophone Studies, vol. 13, no. 1: 131-53.

Burton, R. D.E. \& Reno, F. (eds) 1995, French and West Indian: Martinique, Guadeloupe and French Guiana Today. Macmillan, London \& Basingstoke.

Carruggi, N. 2010, ‘Ecrire en Maryse Condé. Entretien avec Maryse Condé,’ in Maryse Condé: Rébellion et transgressions, (ed.) N. Carruggi, Karthala, Paris: 203-18.

Condé, M. 1995, ‘Chercher nos vérités’ in Penser la créolité, (eds) M. Condé \& M. Cottenet-Hage, Karthala, Paris, 305-10. 1999, Le Coeur à rire et à pleurer: contes vrais de mon enfance. Robert Laffont, Paris. 2001, Tales from the Heart: True Stories from my Childhood, (trans.) R. Philcox. Soho Press, New York. 2006, Victoire, les saveurs et les mots. Mercure de France, Paris. 2007, 'Liaison dangereuse' in Pour une littérature-monde, (eds) M. Le Bris \& J. Rouaud, Gallimard, Paris : 205-16. 2010, Victoire: My Mother's Mother, (trans.) R. Philcox. Atria International, New York. 2012, La Vie sans fards. J.-C. Lattès, Paris.

Ghinelli, P. 2005, Archipels littéraires. Mémoire d'encrier, Montreal.

Glissant, E. 1989, Caribbean Discourse: Selected Essays, (trans.) M. Dash. University Press of Virginia, Charlottesville. 1981. Le Discours antillais. Gallimard, Paris. 1990. Poétique de la relation. Gallimard, Paris. 1997, Poetics of Relation, (trans.) B. Wing. University of Michigan Press, Ann Arbor. 2006, Une Nouvelle Région du monde. Gallimard, Paris.

2007, Mémoires des esclavages: la fondation d'un centre national pour la mémoire des esclavages et de leurs abolitions. Gallimard, Paris.

Glissant, E. \& Chamoiseau, P. 2007, Quand les murs tombent: l'identité nationale hors-la-loi? Galaade, Paris.

Mehta, B. J. 2005, 'Culinary Diasporas: Identity and the Language of Food in Gisèle Pineau’s Un papillon dans la cité and L'Exil selon Julia,' International Journal of Francophone Studies, vol. 8, no. 1: 23-51. 
Nesbitt, N. F. 2002, 'Le sujet de l'histoire: Mémoires troublées dans Traversée de la mangrove et Le coeur à rire et à pleurer' in Maryse Condé: une nomade inconvenante, (eds) M. Cottenet-Hage \& L. Moudileno: Ibis Rouge, Guadeloupe: 113-20.

Nora, P. 1989, 'Between Memory and History: Les Lieux de Mémoire,’ Representations, no. 26: 7-24.

Ovide, S. 2002, French Caribbean Cuisine. Hippocrene Books, New York.

Pfaff, F. 1993, Entretiens avec Maryse Condé. Karthala, Paris. 